\title{
THE POWER OF STATES AS THE BASIS FOR PROMOTING NATIONAL INTERESTS IN THE SYSTEM OF INTERNATIONAL RELATIONS
}

\author{
Colonel Associate Professor Alexandru STOICA, Ph.D. ${ }^{144}$
}

\begin{abstract}
The exercise of national power by each state is an accepted reality of international relations. Its individual power and distribution is one of the major determinants of a state's behaviour in international relations. However, the unlimited use of power by states can be a source of war, anarchy and chaos in international relations. State power, its estimates and measurement tools have always been a matter of interest to political and military leaders, who needed fairly objective parameters to make decisions with fundamental implications for the evolution and behaviour of states in the system of international relations. These issues of state power are the focus of this article.
\end{abstract}

Keywords: power, elements of power, determinants of power, national interests, international relations, quantification of state power.

Entering the 21st century, economic globalisation has not only accelerated the process of integration of the world economy, but also the competition between/among countries, especially between major powers. International competition manifests itself mainly in dynamic changes in the strategic resources of different countries and in open competition to promote national interests through instruments of power. These are often in conflict with each other and locked in dispute, and are, in a complex way, interdependent and interconnected. In the process of development, which is fairly balanced globally, some countries have increased their national power while others, relatively speaking, are losing it. These are the movements that have brought significant changes to the way the contemporary world is organised and functions. A country's status in the international community is essentially associated with the rise and fall of its national power, the rise and fall of its strategic resources ${ }^{145}$.

National power generally means the sum total of a country's powers or strengths in its economy, military structures, science and technology, education and resources and influence. More abstractly, it refers to the combination of all sources of power held by a country for the survival and development of a

\footnotetext{
${ }^{144}$ Colonel Associate Professor Alexandru Stoica Ph.D. is the Head of the Department of Security Studies and Leadership of the National College of Defense.

${ }^{145} \mathrm{https} / / /$ archive.claws.in/images/journals_doc/1302263399_JSBajwa.pdf, accessed 15.05.2021, 20.30.
} 
sovereign state, including material and ideological ethos as well as international influence.

Ashley Tellis ${ }^{146}$ defines national power as a "product of the interaction of two components, one being a country's ability to drive its cycle of economic innovation at a given point in time and the second - the leadership power to shape effective military capabilities, which in turn will lead to the creation of a stable political environment, the enhancement of existing economic advantages, the provision of the basic conditions for maintaining its strategic advantages and the promotion within the international system of national interests". In short, a country's strength can be defined as its overall capabilities to achieve strategic objectives through action at the international level, and the basic factors of the concept are strategic resources, strategic capabilities and strategic results.

Strategic resources of states are defined as the actual and potential key resources available to achieve a country's strategic outcomes. They reflect a country's abilities to use all types of resources globally and also reflect the country's overall strength. Kenneth Waltz ${ }^{147}$ defines powers as the distribution of all types of capabilities. In fact, national power is the distribution of a country's strategic resources that are mobilised and used to achieve its strategic objectives.

\section{ELEMENTS OF STATE POWER}

The power of the nation state depends on several factors that are collectively called components or elements of national power. These factors are also called capability factors. Some scholars prefer to use the term "determinants of national power".

There are a number of elements of national power. Several political scientists have tried to classify them. While Hans Morgenthau ${ }^{148}$ classified them as permanent and temporary elements, Abramo F.K. Organski ${ }^{149}$ preferred to classify them into natural and social determinants - the former including geography, resources and population, the latter being economic development, political structures and national morale.

\footnotetext{
${ }^{146}$ Ashley J. Tellis (PhD, University of Chicago), Advisor to the National Bureau of Asian Research, China's Grand Strategy: A Framework Analysis, p. 35, https://books.google.ro/books?id=hpneDwAA QBAJ\&printsec=frontcover\&hl=ro\&source=gbs_ge_summary_r\&cad=0\#v=onepage \&q\&f=false, accessed 15.05.2021, 21.30.

${ }^{147}$ Kenneth Waltz - founder of the neo-realist movement in international relations, Angang Hu, Economic and Social Transformation in China: Challenges and Opportunities, p. 34, https://books.google.ro/ books?id=2a0y7zFnq2QC\&printsec $=$ frontcover $\&$ hl=ro\&source $=$ gbs_ge_summary_r\&cad $=0 \# v=$ onepage $\& q \& \mathrm{f}=\mathrm{f}$ alse, accessed 15.05.2021, 10 p.m.

${ }^{148}$ Hans Joachim Morgenthau - American political scientist and jurist, theorist of international relations, one of the founders of realism in international relations theory.

${ }^{149}$ Abramo Fimo Kenneth Organski - professor of political science at the University of Michigan, founder of power transition theory.
} 
Abdul Said ${ }^{150}$, Theodore A. Couloumbis ${ }^{151}$ and James H. Wolfe $\mathrm{e}^{152}$ classified these elements as tangible elements and intangible elements - the former category includes those elements, which can be evaluated in quantitative terms, and the latter are ideological and psychological elements and cannot be quantified. Geography, natural resources, population and technology are tangible elements, while ideology, morale, leadership, personality, organisational effectiveness and quality of diplomacy are intangible elements.

Thus, we can speak of the following elements of national power: geography, natural resources, population, economic development, industrial capacity (the power to produce goods), technology, combat capability (the structure, training and equipment of armed forces), ideology (the nation's philosophy in relation to other nations), leadership, organisation and quality of government, national character and morale, and diplomacy.

Among the elements of national power, geography is the most stable, tangible, permanent and natural element. Its importance as a factor of national power can be appreciated by the fact that geopolitical scholars regard geography as a determining factor in international politics. Essentially, a country's foreign policy is determined by its geography, without being an independent determinant of national power or national power itself. It is merely an element of national power.

No state can hope to be truly powerful unless its territory is deeply rooted in natural resources. Natural resources are indeed gifts of nature of established utility. A nation's industrial and military capabilities, as well as its economic wellbeing, are dependent on the existence of natural resources or the way it constructs its policies to gain access to them. A sufficiency in certain key resources can be a great source of a nation's strength. The US has been in a position to be a superpower in the world mainly because of sufficiency in several key natural resources. No nation can be strong without becoming an industrially developed nation, and the chances of becoming an industrialized nation are practically tied to the possession of natural resources, especially industrial raw materials and minerals. Natural resources, in the form of minerals, fertile soil, flora and fauna, through planned exploitation and use, always make a nation strong. Analysing the role of national resources as a factor of national strength, they can be divided into two categories: raw materials and food.

However, the existence of raw materials cannot automatically be a source of power. The ability to exploit and use raw materials is almost as important a factor as their existence. And this ability is directly related to the level of

\footnotetext{
${ }^{150}$ Abdul Aziz Said - senior lecturer in international relations at the School of International Service at American University.

151 Theodore A. Couloumbis - Professor Emeritus of International Relations at the University of Athens.

152 James H. Wolfe - author of Modern International Law.
} 
scientific, technological and industrial progress and the development vision of the country's leaders.

Food is one of the important elements of national strength. Food determines policies at all levels. The existence of large stocks of grain and food is at the lifeblood of a nation. A food-deficit country can rarely become a major power. Food-producing countries are better off than food-importing countries. The acute food problem is a great source of weakness for states in international relations. They are dependent on developed countries with food surpluses or on countries that know how to develop truly competitive economic policies.

The food factor is inseparably linked to other factors, in particular population, science and technology. Food production depends on agricultural technology and industrial capacity (the capacity to process primary agricultural production). The human factor is vital to food production, as it can only be enhanced by human efforts and the application of advanced technology. This also refers to the capacity to exploit marine food products, which are also a source of national strength.

The worst is for countries that also have natural resources and the capacity to produce food, but do not know or do not have the necessary understanding to use for their own benefit what nature has abundantly given them.

Another basic element influencing national power is population. The state with a large number of men and women fit for reproduction and fighting will be more capable of becoming a major power. Human resources continue to be a key factor determining a nation's industrial and military capabilities and its power status in international relations. In this age of artificial intelligence, machines have come to perform a large number of functions previously performed by humans. However, machines have failed to completely replace humans. Even today, the people behind the machines continue to be more important than the machines. Only humans can exploit natural resources and use them to meet their own needs. Geographical obstacles can only be overcome by humans, and scientific and industrial development cannot be achieved without the human factor.

In addition to the size of the population, its quality is a more valuable factor in the context of national power. Only a dedicated, disciplined, hard-working, healthy, educated and skilled human power can be a source of national strength. A country inhabited by people with no ideals, poor health, lazy, unskilled, illiterate and ignorant is doomed to be a weak and inactive power that is easily carried away in international relations.

Therefore, the assessment of population as a factor of national power must involve both quantitative and qualitative evaluation.

A very important indicator is life expectancy, which is a statistical measure of how long a person can live and is influenced by a multitude of factors, mainly demographic. There are many differences in life expectancy between people of the same sex from different regions and between people of different sexes from 
the same region. Social and economic background, gender, a person's individual characteristics as well as genetics or environment play a key role in determining longevity.

Moreover, this indicator of life expectancy shows us the real level of development of the country. The more educated and healthier people live longer, the more you can invest and develop economically. Leaders need to take it into account and make decisions in terms of identifying and implementing the most appropriate policies to increase this indicator.

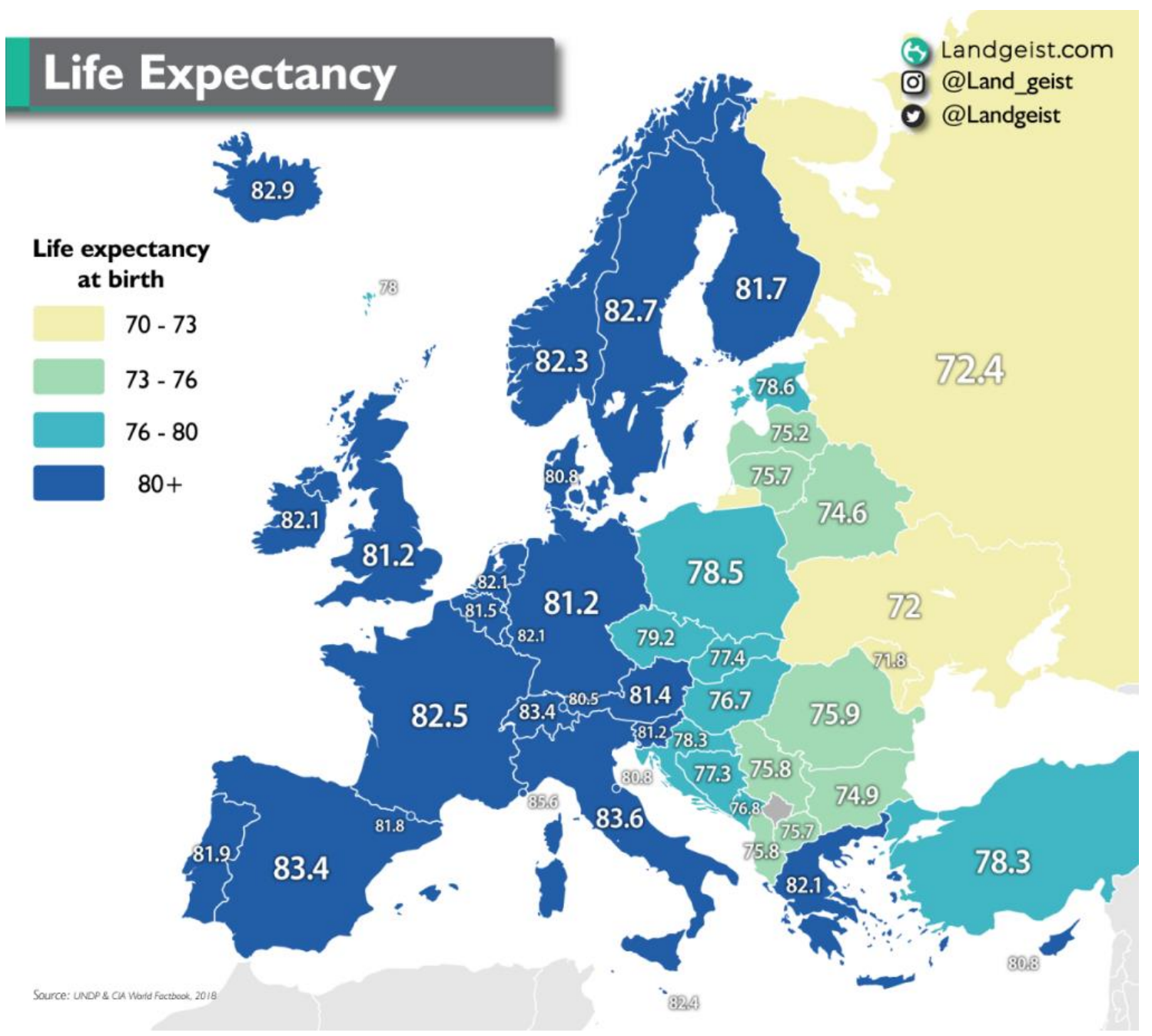

Life Expectancy in Europe ${ }^{153}$

Economic power is a vital part of a nation's strength, as it is the core of military power and the basis of its people's well-being, prosperity and development. Only a state with a developed, healthy economy and a sustainable rate of growth can become a power that matters in regional or global politics.

\footnotetext{
153 https://landgeistdotcom.files.wordpress.com/2021/02/life-expectancy-europe.png, accessed on 14.05.2021,
} 16.30 . 
Effective economic organisation and planning are essential qualities of a strong nation. Poverty is always a source of limiting power. The importance of economic foreign policy instruments is a recognised fact of modern international relations. Only countries with advanced economies can use economic instruments: aid, loans, rewards, subsidies and the refusal of rewards or punishments, to achieve desired goals in international relations. Using economic means, a state seeks to exercise power in a productive and useful way. The level of economic well-being determines a nation's power.

The economic factor is closely linked to a nation's industrial capacity. In this age of artificial intelligence, science, industrialisation and developed technology, only industrial capacity can be a source of sustainable and effective economic development. Only industrially advanced nations can become great powers. Today, the US, China, the UK, France, Japan and Germany are powerful countries because of their huge industrial capabilities. They have the capacity to process all kinds of raw materials, which allows them to control the world economy. So a nation's industrial capacity is an important factor of national strength. At the same time, industrial backwardness, despite the existence of many raw materials, can be a source of weakness for any nation, and especially for those aspiring to change their status in the system of international relations.

From an economic point of view, the situation in 2021 is shown in the following figure (The 50 countries with the largest gross domestic product (GDP) in 2020) ${ }^{154}$ :

\footnotetext{
${ }^{154} \mathrm{https} / / /$ statisticstimes.com/economy/projected-world-gdp-ranking.php, accessed on 14.05.2021, 17.30.
} 


\begin{tabular}{|c|c|c|c|c|c|c|c|c|c|c|}
\hline \multirow{2}{*}{ Country/Economy $\downarrow$} & \multicolumn{6}{|c|}{ GDP (Nominal) (billions of \$) } & \multirow{2}{*}{$\begin{array}{c}\begin{array}{c}\text { Growth } \\
(\%)\end{array} \\
2021\end{array}$} & \multicolumn{3}{|c|}{$\begin{array}{l}\text { GDP per capita } \\
\text { (Nominal) (\$) }\end{array}$} \\
\hline & $2020 \diamond$ & Rank $\uparrow$ & $2021 \uparrow$ & Rank * & $\begin{array}{c}\text { Share } \\
(\%)\end{array}$ & diff $\diamond$ & & $\boldsymbol{A}$ & $2021 \uparrow$ & Rank \\
\hline United States & $20,932.75$ & 1 & $22,675.27$ & 1 & 24.2 & - & 6.39 & & 68,309 & 5 \\
\hline China & $14,722.84$ & 2 & $16,642.32$ & 2 & 17.7 & 6,033 & 8.44 & & 11,819 & 61 \\
\hline Japan & $5,048,69$ & 3 & $5,378.14$ & 3 & 5.73 & 11,264 & 3.25 & & 42,928 & 25 \\
\hline Germany & $3,803.01$ & 4 & $4,319.29$ & 4 & 4.60 & 1,059 & 3.60 & & 51,860 & 16 \\
\hline United Kingdom & $2,710.97$ & 5 & $3,124.65$ & 5 & 3.33 & 1,195 & 5.34 & & 46,344 & 23 \\
\hline India & $2,708.77$ & 6 & $3,049.70$ & 6 & 3.25 & 75.0 & 12.55 & & 2,191 & 144 \\
\hline France & $2,598.91$ & 7 & $2,938.27$ & 7 & 3.13 & 111 & 5.81 & & 44,995 & 24 \\
\hline Italy & $1,884.94$ & 8 & $2,106.29$ & 8 & 2.24 & 832 & 4.15 & & 34,997 & 27 \\
\hline Canada & $1,643.41$ & 9 & $1,883.49$ & 9 & 2.01 & 223 & 5.05 & & 49,222 & 19 \\
\hline Korea & $1,630.87$ & 10 & $1,806.71$ & 10 & 1.92 & 76.8 & 3.59 & & 34,866 & 28 \\
\hline Russia & $1,473.58$ & 11 & $1,710.73$ & 11 & 1.82 & 96.0 & 3.76 & & 11,654 & 64 \\
\hline Australia & $1,359.33$ & 13 & $1,617.54$ & 12 & 1.72 & 93.2 & 4.54 & & 62,724 & 9 \\
\hline Brazil & $1,434.08$ & 12 & $1,491.77$ & 13 & 1.59 & 126 & 3.66 & & 7,011 & 87 \\
\hline Spain & $1,278.21$ & 14 & $1,461.55$ & 14 & 1.56 & 30.2 & 6.38 & & 30,996 & 33 \\
\hline Mexico & $1,076.16$ & 15 & $1,192.48$ & 15 & 1.27 & 269 & 5.00 & & 9,246 & 73 \\
\hline Indonesia & $1,059.64$ & 16 & $1,158.78$ & 16 & 1.23 & 33.7 & 4.30 & & 4,256 & 110 \\
\hline Netherlands & 909.50 & 17 & $1,012.60$ & 17 & 1.08 & 146 & 3.50 & & 58,003 & 13 \\
\hline Switzerland & 747.43 & 18 & 824.73 & 18 & 0.879 & 188 & 3.49 & & 94,696 & 2 \\
\hline Saudi Arabia & 701.47 & 20 & 804.92 & 19 & 0.858 & 19.8 & 2.93 & & 22,700 & 43 \\
\hline Turkey & 719.54 & 19 & 794.53 & 20 & 0.846 & 10.4 & 6.04 & & 9,327 & 72 \\
\hline $\begin{array}{l}\text { Taiwan Province of } \\
\text { China }\end{array}$ & 668.51 & 21 & 759.10 & 21 & 0.809 & 35.4 & 4.75 & & 32,123 & 31 \\
\hline Islamic Republic of Iran & 635.72 & 22 & 682.86 & 22 & 0.727 & 76.2 & 2.54 & & 8,034 & 82 \\
\hline Poland & 594.18 & 23 & 642.12 & 23 & 0.684 & 40.7 & 3.47 & & 16,930 & 49 \\
\hline Sweden & 537.61 & 24 & 625.95 & 24 & 0.667 & 16.2 & 3.06 & & 58,977 & 11 \\
\hline Belgium & 513.09 & 25 & 579.00 & 25 & 0.617 & 47.0 & 4.04 & & 50,103 & 17 \\
\hline Thailand & 501.89 & 26 & 538.74 & 26 & 0.574 & 40.3 & 2.56 & & 7,702 & 85 \\
\hline Nigeria & 429.42 & 27 & 514.05 & 27 & 0.548 & 24.7 & 2.53 & & 2,432 & 142 \\
\hline Austria & 428.62 & 28 & 481.80 & 28 & 0.513 & 32.3 & 3.48 & & 53,859 & 15 \\
\hline Ireland & 418.72 & 29 & 476.66 & 29 & 0.508 & 5.13 & 4.23 & & 94,556 & 3 \\
\hline Israel & 402.64 & 30 & 446.71 & 30 & 0.476 & 30.0 & 4.99 & & 47,602 & 21 \\
\hline Norway & 362.01 & 33 & 444.52 & 31 & 0.474 & 2.19 & 3.86 & & 81,995 & 4 \\
\hline Argentina & 388.28 & 31 & 418.15 & 32 & 0.445 & 26.4 & 5.84 & & 9,122 & 76 \\
\hline Philippines & 362.24 & 32 & 402.64 & 33 & 0.429 & 15.5 & 6.89 & & 3,646 & 124 \\
\hline United Arab Emirates & 354.28 & 35 & 401.51 & 34 & 0.428 & 1.13 & 3.09 & & 35,171 & 26 \\
\hline Egypt & 361.85 & 34 & 394.28 & 35 & 0.420 & 7.23 & 2.47 & & 3,832 & 118 \\
\hline Denmark & 352.24 & 36 & 392.57 & 36 & 0.418 & 1.71 & 2.76 & & 67,218 & 6 \\
\hline Malaysia & 338.28 & 40 & 387.09 & 37 & 0.412 & 5.48 & 6.50 & & 11,604 & 65 \\
\hline Singapore & 339.98 & 39 & 374.39 & 38 & 0.399 & 12.7 & 5.20 & & 64,103 & 8 \\
\hline Hong Kong SAR & 349.45 & 37 & 368.63 & 39 & 0.393 & 5.76 & 4.29 & & 49,036 & 20 \\
\hline Vietnam & 340.82 & 38 & 354.87 & 40 & 0.378 & 13.8 & 6.50 & & 3,609 & 127 \\
\hline Bangladesh & 329.12 & 41 & 352.91 & 41 & 0.376 & 1.96 & 5.04 & & 2,122 & 148 \\
\hline South Africa & 302.11 & 42 & 329.53 & 42 & 0.351 & 23.4 & 3.10 & & 5,444 & 96 \\
\hline Chile & 252.76 & 46 & 307.94 & 43 & 0.328 & 21.6 & 6.17 & & 15,617 & 55 \\
\hline Finland & 270.64 & 44 & 300.48 & 44 & 0.320 & 7.45 & 2.28 & & 54,330 & 14 \\
\hline Colombia & 271.46 & 43 & 295.61 & 45 & 0.315 & 4.87 & 5.15 & & 5,753 & 94 \\
\hline Romania & 247.21 & 47 & 289.13 & 46 & 0.308 & 6.48 & 6.00 & & 14,968 & 56 \\
\hline Pakistan & 262.80 & 45 & 276.75 & 47 & 0.295 & 12.4 & 1.50 & & 1,302 & 162 \\
\hline Czech Republic & 241.46 & 48 & 276.11 & 48 & 0.294 & 0.64 & 4.22 & & 25,732 & 38 \\
\hline Portugal & 231.35 & 49 & 257.39 & 49 & 0.274 & 18.7 & 3.90 & & 25,065 & 40 \\
\hline New Zealand & 209.33 & 50 & 243.33 & 50 & 0.259 & 14.1 & 4.04 & & 47,499 & 22 \\
\hline World & 84,538 & & 93,864 & & & & 6.03 & & 12,152 & \\
\hline
\end{tabular}


According to the latest Global Economic Prospects report, the World Bank estimates that Romania will record a Gross Domestic Product (GDP) growth of $6 \%$ in 2021, 2.5\% more than estimated in January, and next year will record a growth of $4.5 \%, 0.4$ percentage points higher than previously estimated ${ }^{155}$.

The World Bank's global forecast also shows growth this year of 1.5 percentage points to $5.6 \%$, which means the world economy will record its strongest growth in 80 years ${ }^{156}$.

"While there are encouraging signs of global recovery, the pandemic continues to cause pandemics and inequalities for populations in developing countries around the world," says World Bank President David Malpass ${ }^{157}$.

The International Monetary Fund forecasts a strong economic recovery in Romania in 2021, with real Gross Domestic Product growth of 7 percent, while the European Commission forecast shows Romania's economy growing by 5.1 percent in 2021 and 4.9 percent in $2022^{158}$.

Technology applies the knowledge gained in different and multiple fields of science and uses inventions to increase people's well-being. Progress in engineering and industrial production is directly related to the nature and level of technology. Advanced technologies have contributed greatly to the prosperity and power of developed countries. In fact, the level of technical progress determines the status of a country's power. Only a country that relies on advanced technologies can be recognised as a developed nation. The US and other developed countries are technologically advanced countries and this has been a major source of their power.

The ability of a state to develop is largely related to its ability to advance in various fields. Industrial development, the development of means of transport and communication networks, combat capability, economic and social development can only really be possible when a country has access to advanced technologies. The ability to achieve this through its own efforts is a greater source of strength than the ability to import know-how. The inability to develop makes a state dependent on technologically advanced states, which limits its power and opportunities to promote its interests in international relations.

Many developing or underdeveloped countries have not been able to make full use of their natural resources because of the low level of technological development. The role of technology as a factor of national power can be judged by the fact that today technical aid, technological assistance, weapons technology, nuclear technology, information technology, communications technology, dualuse technology and space technology are elements of international relations and all of them influence the foreign policies of both developed and underdeveloped

\footnotetext{
155 https://www.forbes.ro/banca-mondiala-estimeaza-ca-romania-va-inregistra-acest-un-avans-al-pib-ului-de-6217989, accessed 01.06.2021, 20.00.

${ }^{156}$ Ibidem.

${ }^{157}$ Ibidem.

${ }^{158}$ Ibidem.
} 
countries. In this respect, it should be noted that the importance of this factor is linked to other elements such as scientific and industrial potential, raw materials, government policies and, last but not least, the education of the population.

Military power (combat capability) is a vital part of a state's national strength. The importance of the military factor as an element of national power can be judged by the fact that many people consider these two notions to be synonymous. Military power is not the whole of national power, but an important part of it, contributing force and effectiveness to the promotion of national interests.

Combat capability is a basic factor in the success of a foreign policy and is a tangible factor capable of supporting foreign policy and promoting vital national interests. It influences the level of success of foreign policy. All the superpowers and great powers of our age are also great military powers. Three factors are taken into account in assessing combat capability as an element of national power: military technologies and military innovation; military leadership; and the number and quality of military personnel.

Military technologies refer to the nature and type of weapons systems in a state's armed forces. Modern warfare is technologically sophisticated warfare. The quantity and technology of weapons and military equipment is a major factor determining the level of a nation's military strength, and advanced military technologies are always a source of strength and strategic advantage.

Warfare technologies are an important factor, but they can only be fully exploited when supported by effective planning and systematic and efficient use. This highlights the role of military leadership. Military planning is a valuable factor of military action in a military conflict, but only skilful, trained, experienced, loyal, dedicated, energetic and disciplined military leadership can make the best use of weapons, equipment and human resources. Victory is only possible with effective and efficient military leadership.

In an armed conflict, weapons and equipment play an essential role, but their role and effectiveness depend on the number and quality of the fighters. The military equipment and weapons system is important, but not as important as the soldiers who use these weapons and equipment. Their numbers, skill, training, discipline, dedication and morale are the essential factors that can make the effective and successful use of military weapons and technology possible.

We must consider these three factors in order to characterise combat capability as an element of national power. But in addition to the factors listed, combat capability depends on other factors such as technology, industrial capacity, economic development, the state of the economy, government policies and strategic factors. Therefore, combat capability is not an independent determinant of national power. 
In terms of military manpower in 2021, a partial but relevant situation is shown in the following figure (Ranking the total available active military manpower by country, from highest to lowest $)^{159}$ :

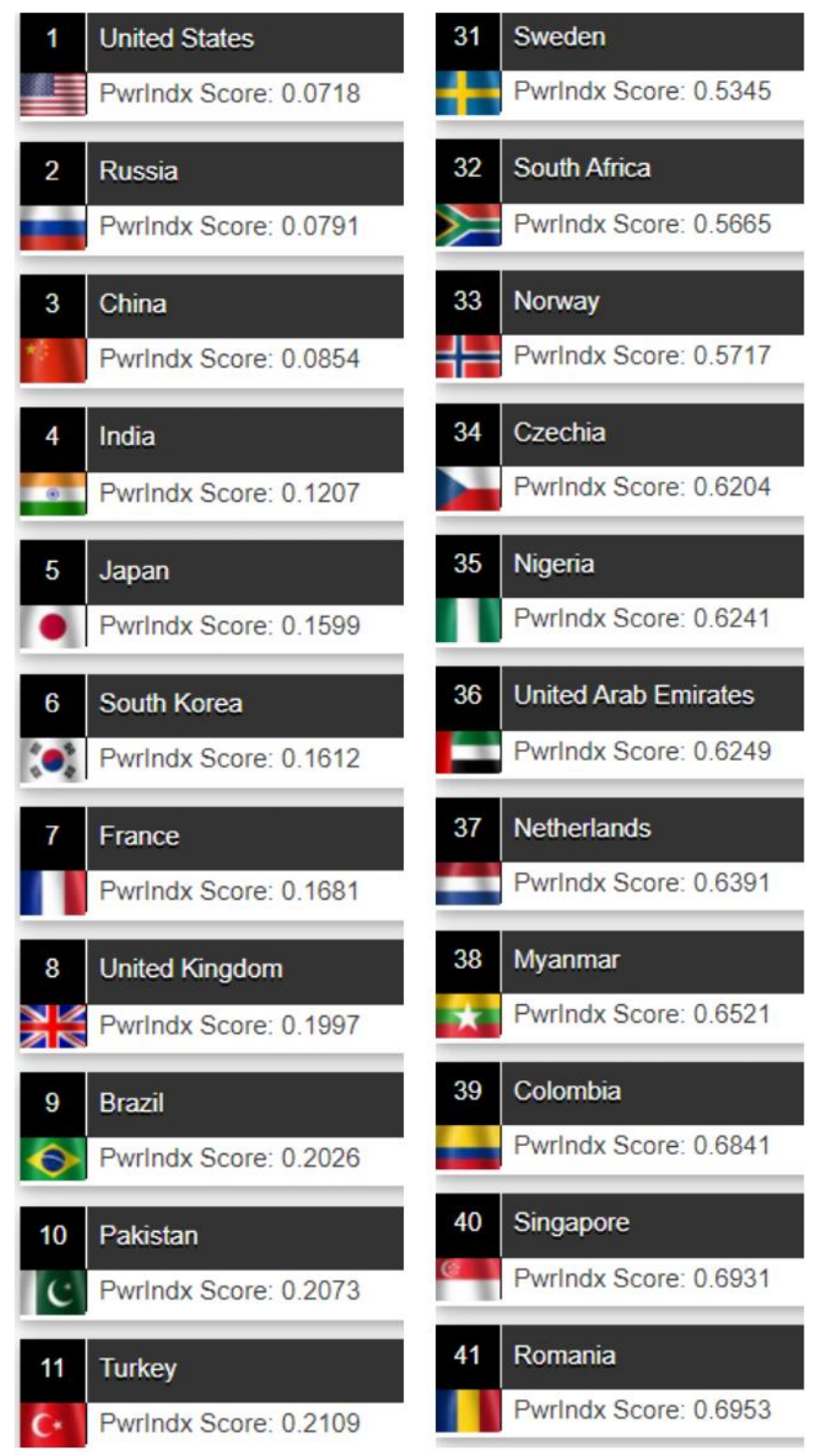

The finalized Global Firepower ranking uses over 50 individual factors to determine a given nation's PowerIndex ('PwrIndx') score with categories ranging from military might and financials to logistical capability and geography.

Ideology (a nation's philosophy in relation to other nations, assumed or imposed) is an intangible element of national power. It can be a source of friendship and enmity in international relations, depending on who you relate to. Ideas and ideologies are elements of a state's power. The pen is mightier than the sword, or at least it has a power that can be a source of strength for a nation. The

\footnotetext{
${ }^{159}$ https://www.globalfirepower.com/countries-listing.php, accessed on 22.05.2021, 20.05.
} 
ideology that a government upholds can be a source of unity and support for nations within or outside state borders.

In assessing the role of ideology as an element of national power, we must also consider the means that a state has at its disposal to propagate its ideology. The means of propaganda and publicity available to a state also act as a factor of national power.

The leadership of a nation is an important human element of national power. The use of human resources, natural resources, raw materials, technology, industrial capacity, military power and ideology to strengthen the national power of a state depends on the qualities of the people who lead the government of a state. Civil and military planning is a function of political leaders. It is the leadership, and in particular the decision-makers of the state, who are responsible for the formulation and implementation of foreign policy. National power is basically the ability of leaders, statesmen and diplomats to have a strong position in international relations. The quality of leadership determines the nature and character of the power a nation can use to defend and promote its national interests. Visionary, effective, committed, loyal and rational leadership can be a source of national power and its operational effectiveness. National power is inextricably linked to the capacity of national leaders and decision-makers.

Organisation and quality of governance. Mere possession of material and human resources cannot lead to national power unless the government of the state in question is well organised, efficient and effective. The government's mission is to coordinate and control human and material resources in such a way that state power ensures the achievement of national interests.

For a nation to become strong, the effectiveness, functionality and organisation of state government and administration is very important.

National character and morale. An important and intangible element of national power is national character. National character is a collective name that refers to the traits of people, their attitude and aptitude towards national work and needs. National character undoubtedly influences national power because it manifests the qualities of people in their actual behaviour.

Scholars tell us that the Russians are known for their endurance, elemental strength and persistence, the Americans for their resourcefulness, initiative and spirit of adventure, the British for their reason and dogmatic common sense, the Germans for their discipline and strength, the Japanese for their nationalism, Indians for their tolerance, idealism and belief in traditions, Chinese for their patience and patriotism, and Romanians for their high potential cognitive/emotional intelligence, creativity and unvalued learning, often defensive personality, behaviour that does not easily obey rules and regulations. National character traits certainly influence the national strength of a state.

Alongside character, morale is also an element of national power. National morale, in the context of national power, refers to the degree of determination with 
which a nation supports its government's foreign policy in peace and war. Morale permeates all the activities of a nation, agriculture, industrial production, military institutions, diplomatic services, etc. High morale means a healthy disposition, which is characterized by dedication and fidelity to the cause. It depends both on the circumstances of the moment and on the quality of leadership and can be subject to frequent, even sometimes sudden, fluctuations.

National character and morale are elements of national power, but their role can be both positive and negative. In addition, their assessment as factors of national power must be made taking into account human and material factors. The intangibility of these factors, in particular national character, must also be taken into account.

Diplomacy is another important element of national power. Hans J. Morgenthau considers it the most important, albeit unstable, element of national power. Diplomacy is the means of foreign policy and, as such, helps it to achieve better results through hard work and persuasion in international relations. The success of a nation's foreign policy depends to a large extent on the quality of diplomacy that is transferred to foreign capitals. High-quality diplomacy can harmonise the aims and means of foreign policy with the resources of national power. Diplomacy can uncover the hidden sources of national power and turn them fully into political reality.

British diplomacy has been instrumental in projecting Britain as a major power in world politics, even after the loss of its imperial status. In the interwar period, the US was very strong politically and militarily, but played a minor role in world politics because of its weak diplomacy.

The role of diplomacy, as an element of national power, has undergone a great change in contemporary times. The emergence of new types of diplomacy open diplomacy and conference diplomacy - has limited its role as a factor of national power somewhat. However, we cannot deny that diplomacy is an important factor of national power, and high quality diplomacy can contribute to the effective and successful exercise of national power.

All elements of national power are important. Those listed above are regarded as major elements of national power. In addition to these, some experts refer to several other elements, such as: the country's reputation in the system of international relations, in response to the challenges of history; external support and ties, i.e. the nature of alliances, treaties, agreements a nation has with other nations; unforeseen events and the nation's reaction to them - in the form of natural calamities or technological breakdowns, which can be described as a source of weakness, versus an unexpected discovery of vital raw materials, which can be a source of strength.

We must consider all these tangible and intangible elements in assessing a nation's national strength. However, we must bear in mind that these factors do not individually determine a nation's national strength. Only when material factors 
are combined with the right kind of human factors do they become factors of national strength. Moreover, their importance and role are constantly changing, depending on the type of interests the state is promoting at any given time.

\section{QUANTIFYING NATIONAL POWER}

A nation with developed technology, surplus food, high industrial production, healthy and developed economy, good natural resources - especially oil, uranium, natural gas, etc., can exercise more power over other nations. Thus, by measuring the volume of a nation's resources and capabilities, we can measure the volume of its power.

There are three variables that are used to measure a nation's national power: area of power; range of power; scope of power.

Quantifying power is a difficult task because it involves the task of quantitatively and qualitatively measuring and analysing a large number of tangible and intangible elements of national power. The need to analyse the actual and potential power of a nation makes the task difficult. However, Karl Deutsch ${ }^{160}$ and other political scientists advocate measuring national power by the three variables listed.

Area of national power. Karl Deutsch defines area as the totality of people whose behaviour is significantly altered by the application of power ${ }^{161}$. He divides the area into internal and external area. The internal area consists of the territory and population of a country. The external area includes those territories and populations outside the nation state that belong to its "sphere of influence". The internal area can be measured in terms of population, surface area and gross national product. The external area can be analysed in terms of its sphere of influence, alliances, dependencies and the degree of penetration into the political processes of other countries. For example, the external area of the USA can be measured in terms of the alliances and organisations to which it belongs, the number of its military bases outside its national territory, and its areas of influence in different parts of the world.

However, measuring area is a difficult task. Areas of influence and degree of penetration cannot be measured empirically. The quality of alliance relationships cannot be measured. NATO in recent decades has been expanding, but recent statements suggest that it would be less effective and less useful. We cannot determine exactly how much influence the US has over France, Germany or Russia, because measuring the extent of power can only be done in a limited way.

\footnotetext{
${ }^{160}$ Karl Wolfgang Deutsch - social and political scientist, Stanfield Professor of International Peace at Harvard University.

${ }^{161}$ National Conference on Elements of National Power, https://www.pc.gov.pk/uploads/pub/4th-CPEC-PaperConference-on-EoNP-2.pdf, accesed on 16.05.2021, 21.30.
} 
The range of national power. Karl Deutsch defines the range of power as the difference between the greatest reward and the heaviest punishment that a wielder of power can bestow or inflict on people under his management ${ }^{162}$. Range is the intensity of power exercised over others. Internal range or intensity of power can be measured by taking into account the use of force and coercion/punishment as well as reward or value distribution for the exercise of power over people. A democratic government uses influence, persuasion and rewards, while a tyrant or dictator uses force and punishment to secure obedience to its policies and laws. The external range or intensity of power can be measured by the means a state uses or can use to secure its desired goals and policies. The number of economic rewards (aid, grants, loans) a nation receives or can receive can indicate the range of power it has in international relations.

However, there is no precise way of measuring the range of a nation's power. We can look at a lot of data to judge "intensity", but we cannot be sure of the real impact of the exercise of power by a strong nation on a weaker nation. The US is the world's largest aid donor and most developed country, but we cannot accurately measure the intensity of its power over other nations, we can only guess.

The scope of national power. The scope of national power means, as Karl Deutsch writes, the totality of all classes of behaviour, relations and affairs that are subordinated to governmental power ${ }^{163}$. The scope of national power consists of all government activities, internal and external. External activities consist in the demonstration of power for the materialization of its own interests. Karl Deutsch's attempt to measure power on the basis of the three variables can only give us some information but not a complete picture of the power of a state. With these we can quantify, to some extent, the national power of a nation, but this cannot help us to determine the national power that a state can exercise over other states. The power of states cannot be measured completely because intangibles and quality factors can never be measured. One way of assessing national power is to evaluate its elements and components. The strength of a state depends on certain tangible and intangible, tangible and intangible, stable and non-stable factors that can be assessed.

\section{ASSESSING THE POWER OF STATES}

By assessing geography, population, natural resources, technology, industrial capacity, military preparedness, diplomacy, government organisation, national character, national morale, leadership and a few other elements, we can have a fairly good assessment of the power of states. However, the assessment of these factors must be made with the utmost care and objectivity. In order to do this, the following factors and characteristics must be taken into account and must

\footnotetext{
162 Ibidem.

${ }^{163}$ Ibidem.
} 
guide every assessment of state power: the relative and comparative nature of power; the dynamic nature of the elements; the interdependence of all factors; the quantitative and qualitative assessment of factors; the ability to use resources; the level of combat readiness; the need to measure both actual and potential power.

\section{Relative and comparative nature of power}

All elements of national power must be assessed in relation to those of other states, especially neighbours and competitors, rivals and adversaries. An independent and isolated assessment of a nation's national power will never be realistic, and may even be suicidal.

\section{The dynamic nature of national power}

The relative importance of the elements of national power is always changing. In our times of rapid technological change, the relative importance of various elements has been constantly changing. Oil has replaced coal as the main fuel source and may soon be replaced by other types of energy. Uranium may lose its value if solar energy is used and developed to cause atomic fusion. Military technology is also a rapidly changing technology. A powerful weapon may become obsolete after a few years. We must therefore take into account the dynamic nature of the various elements, assessing their role as elements of state power.

\section{Interdependence of all factors}

Most importantly, no single element of national power is or can be a determinant of national power. No nation can dream of power if it lacks some elements. All factors of national power are interdependent and they must be assessed as a single group.

\section{Quantitative and qualitative assessment of factors}

Assessing the elements of national power must involve both quantitative and qualitative analysis. Simple numbers are meaningless. For example, a large territory and a large population without ideological qualities can never be a source of power. The number of aircraft is important, but alongside this, the range, speed, weapons systems, payload and operational role, training and commitment of pilots are equally important and must be taken into account.

\section{Ability to use resources}

The existence of certain elements does not condition national power. Only when the nation has the ability to effectively use the elements that lead to national power will it evolve.

\section{Level of combat readiness}

Combat readiness should not be neglected in assessing the role of elements of national power. A distinction must be made between trained active soldiers and those to be mobilised. In the age of modern technologies, combat readiness has become a vitally important factor of national power. Modern warfare has virtually become a war of time, as the ability to strike first and the ability to respond to the first blow can together be a determining factor in the outcome of war. 


\section{The actual and potential importance of power elements}

Analysis of the various elements should not be limited to the available data about the present or the near past. The analysis must include an estimate of trends in both the elements of power that are currently considered important and those that will become important in the future. Both the current and potential positions of the various elements should be analysed to assess their present and future role as elements of national power. All these features must determine the analysis of national power factors. Without attention to them, conclusions about the assessment of national power are wrong and misleading. Assessing national power is indeed a difficult and complex task. But to be successful, objectivity must be maintained and possible errors eliminated. In addition, the assessment must be continuous and systematically repeated.

\section{CONCLUSIONS}

The exercise of national power by individual states is an accepted reality of international relations. Individual power and its distribution is one of the major determinants of a state's behaviour in international relations. However, the unlimited use of power by states can be a source of war, anarchy and chaos in international relations. Humanity is fully aware of the dangers of unregulated use of national power by individual states. Today, states themselves realise their major interdependence and the need to restrict the use of power. In the nuclear age, the danger resulting from unrestricted use of power implies the possibility of total destruction of mankind through nuclear war. The new need for sustainable development at all levels has again forced all nations to accept the need to control and regulate the use of power by all states in the interests of preventing war and anarchy in international relations.

At present, the pandemic that began in 2021 is arguably the most important challenge of the 21st century. In fact, it has triggered many comments that it will bring with it a transformation on a global scale. The most notable of these comments predict a change in the world order. Many experts suggest that a new world order will emerge, insisting that the current order will face pressures. Of course, there is no doubt that we are entering a new period on a global scale. However, it cannot be said that the world order will undergo a radical change after the coronavirus epidemic and that this is inevitable.

When we look at world politics over the last five centuries from the perspective of the world order specific to each era, we see that three basic elements come to the fore: power distribution, economics and international norms/rules. While the distribution of power determines the basic course of competition between (great) powers, the economy determines the rules of the system, and international rules directly determine international processes and partly the behaviour of state actors. In a system where the distribution of power is shared between more than three states, the world order is multipolar/polycentric, when it 
is shared between two powers, it is bipolar, and when there is only one actor, it is unipolar.

Throughout history, major wars have caused a new balance in the existing distribution of power, with the world order being reconstructed after each war on the basis of a new paradigm. The economic system and rules that form the core of this paradigm determine the positions, roles and modes of action of states on a global scale. States either adapt to the system, resist it or strive to be included in the system in order to take advantage of it.

For the post-Pandemic COVID-19 world order to be replaced by a new one, the coronavirus epidemic must bring about a change in the current distribution of power, in parallel with which the economic structure and the actor or actors that will control it must carry out structural reforms that will bring about changes in the mechanisms of the system's functioning and be able to create new global regimes along the lines of the new rules. But this is unlikely to happen.

\section{BIBLIOGRAPHY}

- Deutsch K.W., Problems of World Modeling: Political and Social Implications, Published by HarperCollins Publishers, 1977.

- Kissinger H., Diplomacy, ALL Publishing House, Bucharest, 2003.

- Kissinger H., The World Order - Reflections on the Specificity of Nations and the Course of History, RAO Publishing, Bucharest, 2015.

- Morgenthau H.J., Politics between nations. The struggle for power and the struggle for peace, Polirom Publishing House, Bucharest, 2013.

- https://archive.claws.in/images/journals_doc/1302263399_JSBajwa.pdf.

- https://books.google.ro/books?id=hpneDwAAQBAJ\&printsec=frontcover\& $\mathrm{hl}=\mathrm{ro} \&$ source=gbs_ge_summary_r\&cad=0\#v=onepage \&q\&f=false.

- https://books.google.ro/books?id=2a0y7zFnq2QC\&printsec=frontcover\&hl= ro\&source=gbs_ge_summary_r\&cad=0\#v=onepage $\& \mathrm{q} \& \mathrm{f}=\mathrm{false}$.

- https://landgeistdotcom.files.wordpress.com/2021/02/life-expectancyeurope.png.

- https://statisticstimes.com/economy/projected-world-gdp-ranking.php.

- https://www.forbes.ro/banca-mondiala-estimeaza-ca-romania-va-inregistraacest-un-avans-al-pib-ului-de-6-217989.

- https://www.globalfirepower.com/countries-listing.php.

- https://www.pc.gov.pk/uploads/pub/4th-CPEC-Paper-Conference-on-EoNP2.pdf. 